\title{
TACCA PLANTAGINEA (HENCE) DRENTH (TACCACEAE) - A NEW ANGIOSPERMIC RECORD FOR BANGLADESH
}

\author{
M.A. $\operatorname{HASSAN}^{1}$ AND MoHAMmad ZASHIM UdDiN ${ }^{2}$ \\ Department of Botany, University of Dhaka, Dhaka 1000, Bangladesh \\ Key words: Tacca plantaginea, New record, Bangladesh
}

The genus Tacca Forst., under the monogeneric family Taccaceae, is represented by ten species, nine in the tropics of the Old World and one in tropical South America. It is well-developed in Malesia, where eight out of nine Old World species occur (van Steenis 1975). Hooker (1892) recorded four species from the whole of British India (including present Bangladesh), out of which only two ( $T$. pinnatifida J. R. \& G. Forst. $=T$. leontopetaloides (L.) O. Ktze. and T. integrifolia Ker-Gawl.) stand valid and the other two (T. cristata Jack and T. laevis Roxb.) became synonyms under T. integrifolia (van Steenis 1975, Phengklai 1993).

Tacca is so far represented by three species in Bangladesh, viz., (i) $T$. leontopetaloides (L.) O. Ktze. (syn. T. pinnatifida J.R.\&G. Forst.), (ii) T. integrifolia KerGawl. (syn. T. cristata Jack, T. aspera Roxb. and T. laevis Roxb.), and (iii) T. chantrieri Andre (Hook. f. 1892, Prain 1903, Sinclair 1955, van Steenis 1975, Phengklai 1993, Uddin et al. 1998, Lemmens and Bunyapraphatsara 2003, Uddin and Hassan 2004).

A sterile tiny specimen of Tacca was collected from Rema-Kalenga Wildlife Sanctuary while the area was floristically explored during 1998-2001 and planted in the Dhaka University Botanical Garden. The plant grew well and after about five years it flowered in October 2006. This live specimen has been identified as Tacca plantaginea (Hence) Drenth, following the description and illustration given by Phengklai (1993). Tacca plantaginea is so far known from South China (Type), Vietnam, Laos and Thailand (Phengklai l.c.), hence it has been reported here as a new record for Bangladesh.

A detailed taxonomic description of the species has been prepared and photograph provided based on the live specimen conserved at the Dhaka University Botanical Garden.

Tacca plantaginea (Hence) Drenth, Blumea 20: 391 (1972). Schizocapsa plantaginea Hence, J. Bot. 19: 292 (1881).

(Plate 1)

A perennial herb with cylindrical rhizome. Leaves 3-4 together, rosulate, petiolate, $17 \times 4.5 \mathrm{~cm}$, lanceolate, margin entire, apex acute to acuminate, base gradually merging into the petiole, petiole up to $15 \mathrm{~cm}$ long, channelled on the upper surface. Inflorescence

\footnotetext{
${ }^{1}$ Corresponding author. ${ }^{2}$ E-mail: zashim07@yahoo.com
} 
1-2, scape simple, up to $7 \mathrm{~cm}$ long, up to 13-flowered. Involucral bracts 4, arranged in 2 pairs, decussate, sessile, green, outer 2 ovate-lanceolate, longer one $6.3 \mathrm{~cm}$, number of bracts correlates with the number of flowers. Flowers pedicellate, light green, actinomorphic, trimerous. Tepals $3+3$, in two series, outer 3 c. $9 \times 4 \mathrm{~mm}$, inner 3 c. $7 \times$ $6 \mathrm{~mm}$, broadly ovate. Stamens 6, light green, each opposite to a tepal, filaments short,

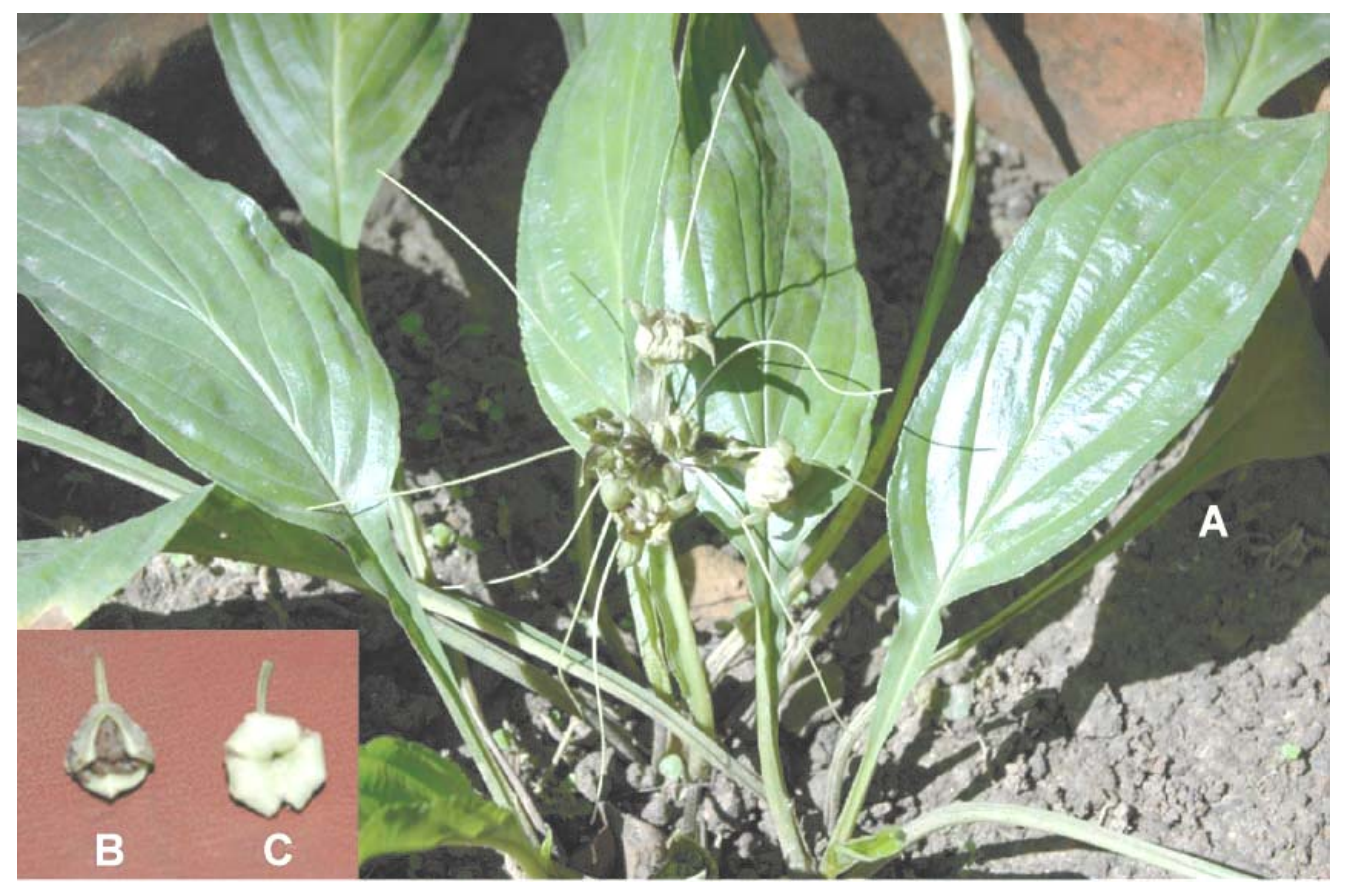

Plate 1. Tacca plantaginea. A. habit; B. a capsule; C. a bursting capsule (seeds dropped out).

c. $1 \mathrm{~cm}$ long, anther broad, c. $3 \mathrm{~cm}$. Carpels 3, 6-ribbed, united into a compound inferior ovary, one chambered, placentation parietal, ovules many. Fruit a capsule, triangular, dehiscent, bursting longitudinally into 3 valves, valves reflexed. Seeds oblong-ovoid, grey in colour, longitudinally striped. Flowering and fruiting: October-February.

Distribution: South China (Type), Vietnam, Laos and Thailand.

\section{References}

Hooker, J.D. 1892. Fl. Brit. Ind. 6: 286-288. L. Reeve \& Co. Ltd., Kent, England.

Lemmens, R.H.M.J. and Bunyapraphatsara, N. (eds.) 2003. Plant Resources of South-East Asia No. 12(3). Medicinal and poisonous plants 3. Prosea Foundation, Bogor, Indonesia, pp. 664.

Phengklai, C. 1993. Taccaceae. In: Smitinand, T. and Larsen, K. (eds.), Flora of Thailand 6, Part I. The Forest Herbarium, Royal Forest Department, Bangkok, pp. 1-9.

Prain, D. 1903. Bengal Plants 2: 1092-1093. Indian reprint (1996), Bishen Singh Mahendra Pal Singh, Dehra Dun, India. 
Sinclair, J. 1955. Flora of Cox's Bazar, East Pakistan. Bull. Bot. Soc. Bengal 9(2): 84-116.

Uddin, M.Z. and Hassan, M.A. 2004. Flora of Rema-Kalenga Wildlife Sanctuary. IUCN - The World Conservation Union, Bangladesh Country Office, Dhaka, Bangladesh, vi + pp. 120.

Uddin, S.N., Khan, M.S., Hassan, M.A. and Alam, M.K. 1998. An annotated checklist of angiospermic flora of Sita Pahar at Kaptai in Bangladesh. Bangladesh J. Plant Taxon. 5(1): 13-46.

van Steenis, C.G.G.J. (ed.) 1975. Flora Malesiana 7. Part 4. Noordhoff International Publishing, Leyden, The Netherlands, pp. 806-819.

(Manuscript received on 12 March 2007; revised on 12 April 2007) 